\title{
Brief Analysis on the Archiving Construction of Afanty Data*
}

\author{
Abuduwaili Keremu \\ School of Uyghur Language Culture \\ Northwest Minzu University \\ Lanzhou, China 730030
}

\author{
Amina \\ School of Uyghur Language Culture \\ Northwest Minzu University \\ Lanzhou, China 730030
}

\begin{abstract}
Afanty is the well-known folk wise character of China. His character with humor, intelligence, braveness and wisdom has been incisively and vividly manifested in folktales. The story of Afanty has been widely spread in folk in the modes including oral spreading, word spreading, video spreading and many other kinds of carriers which has gradually become the precious folk cultural wealth of China and moved towards the process of localization and chinization. To protect the excellent cultural heritages and promote the cultural confidence, we need to further collect and organize the stories about Afanty and the various kinds of carriers and archive the words, audios and videos so as to finally realize the goal of digital archiving and effectively protect our cultural heritages.
\end{abstract}

Keywords-Afanty; tale data; archiving construction

\section{INTRODUCTION}

As the well-known folk artistic image, Afanty is deeply liked and loved by people of all nationalities of China. Afanty satirized, castigated and criticized the feudal characters including the king, prime minister and lord Bayi, etc with the qualities including intelligence, courage, gut and goodness, etc and vented the anger for the masses and therefore gradually became the patron saint of the masses symbolizing positive energy. With the development of media, the image of Afanty has been spread through multiple approaches including words, films and internet, etc and has been gradually and widely spread in folk of various nationalities in China, especially the uygur which represented the Chinese cultural identity of 56 nationalities of China.

\section{INTRODUCTION OF AFANTY DATA}

The folk literature of China is very various and abundant and the 56 nationalities all have their respective literary classics. Thereinto, the excellent folk literary classics dominate. Most of minorities of China dictate the memories of excellent folk culture inheritance. And the oral culture inheritance is the literary tradition features of national multiple nationalities, such as the three great epics including Epic of King Gesar, Epic of Jangar and Manas Epic which are all the excellent folk literary classics orally passed on generation by generation. After the founding of the People's Republic of China, under

*This paper is one of the achievements of general project funded by basic scientific research business funds of Central College of Northwest Minzu University- "Compilation of Afanty Tales Study Data" (31920170048)]. the care of the Party and state, those word records and audio records are all well preserved. Afanty is the excellent folk literature organization of people of all nationalities in Xinjiang which has been passed on generation by generation in the oral teaching mode till nowadays, especially widely spread in Uyghur, Kazak and Ozbek nationalities. Currently, it has been widely spread and accepted among various nationalities of China through multiple modes including translation, introduction, animation production, film-making and dramas as well as acting, etc. In the various places centered on Xinjiang, the tale of Afanty has been continuously created, revised and developed which can continuously enrich the treasury of Afanty folk tales.

\section{A. Afanty and Literal Tale Data}

It is the first time that Afanty became the paper folk literature from mouth to mouth of the masses. Mr. Zhao Shijie and Ekber Uram compiled and published the funny tales of Afanty on the magazines including Xinjiang Literature and Art, Western Literature, National Literature and Chinese Folk Culture, etc. In the summer in 1957, Zhao Shijie published the carefully selected 100 Afanty Tales in Shanghai Culture Press with the volume of 20 thousand. After 1958, China has successively published 14 versions of Afanty Tales in five kinds of words including Chinese, Uygur language, Mongol, Kazakh and Tibetan, the versions mainly compiled among which include 393 tales and this makes it the relatively complete version so far. The Afanty Tales published in 1962 in China Juvenile and Children's Books Publishing House became the bestseller at that time which has been successively reprinted for four times. Right after that, China Juvenile and Children's Books Publishing House collected and published 380 thousand volumes of Afanty Tales. In 1986, the book, Afanty and "Afanty"-s compiled by Zhao Shijie was published by Guangming Daily Press where the Afanty tales of Uyghur nationality and Ozbek nationality were compiled in it. And it also compiled the funny tales of wise characters like Afanty of Uyghur, Hui nationality, Kazak, Mongol nationality, Khalkhas and other nationalities in Xinjiang. In 1990, Zhao Shijie selected, compiled and published the book, Selection of Uygur Folk jokes where the Afanty tales took up most part of the length. Mr. Ge Baoquan published Afanty Tales in 1981 as editor-in-chief (China Folk Literature and Art Press). In 2006, Mr. Ekber Uram compiled Afanty Classic Jokes (6 volumes) which are published by Xinjiang Juvenile Publishing House. 
He also compiled the World Afanty Jokes Compilation. In 2006, Xinjiang People's Publishing House published serial books of uygur folk literatures, thereinto Uygur Jokes was included in Afanty funny tales. The writer, Mr. Aihetanmu Wumaier created the fiction, Nasretdin Afanty. As the cultural publishing industrial mode, the serial Afanty funny tale books have laid the foundation for Afanty culture industry development.

According to the statistics, there are over 300 Afanty tale books, including organized tales books, translated and edited tales books, rearranged tales books and compiled tales books, original creation books and other different types. Quantitatively, the main distribution conditions are as follow:

The book types are divided into 52 translated and edited tales books, 23 revised books, 73 drawing books, 6 original books and 152 other books.

The percentages respectively are $15 \%, 12 \%, 21 \%, 2 \%$ and $50 \%$. From that, we can see that the percentage of other books is highest, accounting for $50 \%$; there are 73 drawing books accounting for $21 \% ; 21$ translated and edited books accounting for $15 \% ; 6$ original books, only accounting for $3 \%$ which is the lowest.

\section{B. Afanty Audio and Video Data}

In 1970s, the puppet show, Afanty Tales produced by Shanghai Animation Film Studios is the foundation and precondition of Afanty animation and cartoon industries. In 2011, the Propaganda Department of Xinjiang Uygur Autonomous Region cooperated with Ningbo Minhe Media Co., Ltd and Institute of Automation, Chinese Academy of Sciences undertook the production to jointly produce the threedimensional animation, Young Afanty and over 30 episodes have been broadcast at CCTV-14 Children's Channel. And it is planned to produce 104 episodes which is under the development and production works. In addition, Xinjiang acrobatics troupe recorded the acrobatic show- Hello, Afanty which has been displayed for over 100 times all over China. The exploration of Afanty animation industry will play an important role in the economic belt of Silk Roads.

In 1980s, the file with the theme of Afanty filmed by Xinjiang Tianshan Film Studios was started by Tuyigong Aihemi which caught strong response at home and abroad. This film took scattered Afanty funny tales as main film lime which reflected the conflicts between folk wise characters and the federal upper class and described the lovely and smart Afanty image.

\section{AFANTY ARCHIVING CONSTRUCTION}

Under the high attention of the Party and state and the great efforts of cultural administration departments, Afanty and its tale data base have been preliminarily established. As the composition of multiple nationalities excellent culture treasury of China, the collection and organization of Afanty tales data and archiving construction possess significant reference values and social meanings. To further perfect the construction of data base, the classified archiving and digital archiving construction in respect of Afanty and his tales data are very valuable.

A. Measure of Classified Archiving: Classify the Afanty Data into Three Categories According to the Actual Conditions of Afanty Data and We Should Conduct Archiving According to Three Forms

1) Oral data archiving: Collect the Afanty funny tales, Afanty sarcasm tales and Afanty wisdom tales according to oral data, audio and video data. We need to to conduct comprehensive collection and organization to the Afanty tales in folk oral form and conduct data archiving to such tales.

2) Word data archiving: The word data of Afanty is divided into formal publications and informal publications. The Afanty word data publications can be divided into Afanty tales books, Afanty biography books, Afanty study books and Afanty fiction books, etc. The informal publications include transcripts of ancient writing books and ancient books in modern and contemporary Uygur, Uzbek and Kazak, etc. Currently, the word data of Afanty tales classified based on language is richer. And there are also the Afanty ancient books in multiple languages including Chinese, Mongolian, Tibetan, Uyghur, Kazakh and Kirghiz, etc. We should construct data files to such data in classifications to protect and develop such data.

3) Audio data archiving: Since the puppet show, Afanty Tales produced by Shanghai Animation Film Studios, China has successively produced Afanty, Yound Afanty, Hello, Afanty and Donkey Friend, Afanty and other films, animations, TV plays and acrobatics which have been widely broadcast on TV, cinemas and the internet and have been well accepted by broad masses. This is the main source for production of large quantity of audio and video data. We need to conduct overall classification in term of this and conduct coding, archiving and protection.

\section{B. Digital Archiving}

China is a large internet country and the quantity of netizens is in the increasing development trend on a daily basis. To provide convenience for readers and researchers, we need to digitize the paper archives which are a main process for the modernization of archive management of China. Its basic link mainly includes archives arrangement, content database building, archive scanning, image processing, image storage, data quality inspection, data hooking, data acceptance, data backup and achievement management and other process. We need to build a network database platform to organize the carriers of Afanty data literature based on oral data, word data and multimedia (image, audio and video, etc) data and produce the main content, subdirectory and subcatalog according to classifications, then conduct scanning and image processing in respect of Afanty paper data and store such data through multiple kinds of data carriers including words, images, audios and video data, etc. We need to input and scan the paper data including manuscripts of Afanty tales and Afanty tales books, etc and expand the contents on database platform. At the same time, we need to load the video data including Afanty TV, 
films and animations, etc into the multimedia database to further enhance the construction of Afanty database. We also need to open the user application window on database platform to let users log in the platform through registration procedures in formal identity and search the electronic materials according to classifications, contents, themes and key words. Conduct the comprehensive and systematic digitization to the Afanty data.

\section{CONCLUSION}

In a word, the archiving of Afanty data is the exploration in the archiving development of folk literature data of China and is an attempt for development of monographic study and archiving of works data which provides a working idea for the modern construction of folk literature data archives of China. We will enhance the collection, organization and archiving of Afanty data, build a network platform of Afanty data and archives to provide a network platform for the readers, learners and researchers of Afanty.

\section{REFERENCES}

[1] Abduwal Keram, Afanty: Envoy of Cultural Communication [N]. Social Sciences in China Press, July 2015 (23). 阿布都外力.克热木. 阿凡 提：文化交流的使者[N]. 中国社会科学报，2015，7（23）.

[2] Abduwal Keram. Afanty Cultural Industry under the structure of Silk Road Economic Belt[J]. China Business, October 2014 阿布都外力.克 热木. 丝绸之路经济带格局下的阿凡提文化产业 $[\mathrm{J}]$. 全国商 情. 2014.10.

[3] Abduwal Keram. "Afanty" Phenomenon: Afanty Legends Providing New Thoughts for Xinjiang Cultural Industrial Development[J]. China Ethnic News, November 6, 2015.阿布都外力.克热木. “阿凡提”现 象: 为新疆文化产业发展提供新思路阿凡提传奇 $[\mathrm{J}]$. 中国民族 报，2015.11.06.

[4] Afanty entries: Baidu Baike baike.baidu.com/[W]. October 3, 2013. 阿 凡提词条: 百度百科 baike.baidu.com/[W]. 2013-10-03.

[5] Ekber Uram. Afanty Legends [M]. Wuhan: Hubei Juvenile Press, 2008. 艾克拜尔. 吾拉木. 阿凡提传奇 $[\mathrm{M}]$. 武汉: 湖北少儿出版社, 2008.

[6] Ge Baoquan. Afanty tales[M]. Beijing: China Juvenile and Children's Publishing House, 1962. 戈宝权. 阿凡提故事[M]. 北京: 中国少年 出版社, 1962 .

[7] Wu Heng. Electronic Construction of Auxiliary Archives for Study on Prefecture-Level Libraries [J]. Library Construction. July 2004. 吴街. 地 市级图书馆研究辅导档案资料电子化建设[J]. 图书馆建设. 2004.07.

[8] Zhao Shijie. Afanty's Stories [M]. Shanghai: Shanghai Literature and Art Press, 1958. 赵世杰. 阿凡提的故事 $[\mathrm{M}]$. 上海: 上海文艺出版 社, 1958 .

[9] Zhao Shijie. Afanty and "Afanty"-s [M]. Beijing, Guangming Daily Press, 1986. 赵世杰. 阿凡提及“阿凡提”们[M]. 北京: 光明日报出 版社, 1986.

[10] Zhao Shijie. Selection of Uygur Folk jokes [M]. Lanzhou: Dunhuang Literature ad Art Press. 1991.赵世杰. 维吾尔民间笑话精选[M]. 兰 州: 甘肃敦煌文艺出版社, 1991 . 